\title{
EXAMINING THE RELATIONSHIP BETWEEN STRATEGIES OF ORGANIZATIONAL CULTURE AND ORGANIZATIONAL EFFECTIVENESS IN GOVERNMENT OFFICES
}

\author{
Sairan Tahmasebi \\ MSc Student of Management, Department of Management, Sanandaj Branch, Islamic Azad \\ University, Sanandaj, Iran \\ Ataollah Mohammadi \\ Assistant Professor in Accounting, Department of Management, Sanandaj Branch, \\ Islamic Azad University, Sanandaj, Iran \\ Kiumars Ahmadi \\ Assistant Professor in Management, Department of Management, Sanandaj Branch, Islamic Azad \\ University, Sanandaj, Iran
}

\begin{abstract}
The main objective of this study is to examine the relationship between strategies of organizational culture and organizational effectiveness in the public sector offices. This applied research uses a descriptive approach and conducted as a correlational study. The data collected using a questionnaire with 51 items and a high validity and reliability, such that the reliability of questionnaires that calculated for the variables using Cronbach's alpha (strategies of organizational culture and organizational effectiveness) are 0.786 and 0.859 . The statistical population of the study includes all the employees of the government departments of Sanandaj city in 2016. The questionnaires were distributed using the random sampling method and in the end among the 253 distributed questionnaires, 250 questionnaires were studied analyzed using parametric statistical tests (correlation and regression). The findings of the study suggest that there is a significant and positive relationship between strategies of organizational culture and organizational effectiveness and the correlation coefficient is equal to 0.250. Among the strategies of organizational culture, the participatory culture has a significant and direct relationship with organizational effectiveness, and the mission culture has a significant and inverse relationship with organizational effectiveness and no significant relationship observed a flexible between culture and a hierarchical culture.
\end{abstract}

Keywords: organizational culture, organizational effectiveness, employee, provincial governor

\section{INTRODUCTION}

Strategies of organizational culture are among the necessary and background factors that have been under focus in the strategic management's literature (Arabi and Moghaddam, 2007). One of the indicators of an organization's power is having an organizational culture that is a reflect its characteristics, strengthens and weaknesses that can present its inside and outside image in terms of dedication of employees to values, principles, beliefs, attitudes and other matters related to beliefs. By studying organizational culture, a firm can discover its employee's cohesion of values. The more cohesion of values and commitments is the easier it is to achieve organization's goals (Abzri and Daloii, 2009). Execution of strategies in an organization is successful when other proceedings and activities in the organization are coordinated and aligned with each other (Rafii and Zahedi, 2012). In addition, alignment of human resources systems and business strategies and other systems will increase business performance (Rahmanseresht, 2006). 
Nowadays, one of the features of organization's activity field is becoming more competitive and as a result more unstable. Along with the increased competition in the market, decision-making and policy for survival or business success become more complex. In such conditions, strategic planning and selection of appropriate strategies are of special importance for organizations (Ghadami and Lacani, 2015). Researchers believe that qualification of an organization for implementation of strategy depends on hardware and software infrastructure; because its culture and norms, counts as the software infrastructure (Gupta, 2010). The successful Execution of strategy is subject to the dominant culture support of society or organization. Thus, in almost all strategy models, organizational culture is an important element (Gupta, 2010), as proposed by Hersey et al (1998), organizational culture is the foundation for organizational evolution and strategies (Moshbeki, 2001).

The organizational effectiveness theory has a long, contradictory and complex history and researchers have confirmed the multidimensionality of organizational effectiveness. Some of these approaches include approaches based on goals (Price, 1968), approaches based on system resources (Milyz, 1980), organizational internal processes approaches (Chatman and Cishore, 1967), satisfaction of strategic stakeholders groups approach (Connolly et al, 1980), competitive values approach (Queen and Rorbach, 1983), and double level approach (Baldok and Bulnes, 2008) (Faqimahmoud, 2012). Rojas (2000), after studying the most important approaches of effectiveness in non-profit organizations, showed that competitive value approach is the most appropriate approach for assessment of effectiveness organizational among non-profit organizations. On the other hand, Shillbury and Moore (2006) state that the satisfaction of stakeholder groups approach is the prerequisite and constituent components of competitive value approach. Campbell (1977) states that effectiveness is relative; if we look at organizations from this perspective, effectiveness become a "multidimensional" phenomenon subject because effectiveness at a range or in one field cannot relate to the necessity of effectiveness of a field or a part of the organization (Habibi et al, 2013).

Nowadays, the role of organizations is clear in the development process of societies and the present question is that why some organizations are successful and some fail to perform their duties. Answering such question requires extensive studies on the factors linked with the effectiveness of organizations. They have found many key and common factors by studying different agencies, which is the focus of the future researchers (Omidi et al, 2012). Many researchers such as (Kernis, 2001; Cameron, 2005; Martz, 2008; and Burke, 2010) have investigated the role of organizational effectiveness in big and governmental organizations (Faqi Mahmoud, 2012). The results of past studies by researchers such as Shine (1992), Fisher (2000), Denison and Johnnies (2007) and others show that the organizational culture is one of the most important factors that affects organizational effectiveness (Omidi et al, 2012). Provincial Governments, in their territories that perform their missions as the main representative of the government, are responsible for implementing general policies with ministries, institutions and governmental companies and other governmental bodies. It seems that organizational culture, in the Provincial Government of Sanandaj city, can increase the organizational effectiveness and improve the reaction speed of the Provincial Government to challenges and environmental changes and crises.

\section{RESEARCH METHODOLOGY}

In terms of data collection, this research is a descriptive type. Further, since in the study we attempt to determine the relationship between organizational culture and organizational effectiveness, this research is a correlational research and considering data collection, it is a sectional research type that is conducted between the April and September of 2016. Since its goal is to determine the variables' correlation in the Provincial Government of Sanandaj city, it is a field study. The statistical population of the study in this research includes all employees of Provincial Government of Sanandaj city. To assess strategies of organizational culture (Denison and Noel, 2006) used 40 questions that include 10 questions for each component of corporate culture. To measure organizational effectiveness (Pirgheybi, 2013); used 11 
questions. Cronbach's alpha coefficient for organizational culture and organizational effectiveness are 0.786 and 0.859 respectively, which represents the stability and internal consistency of the questionnaire.

\section{RESULTS}

The first demographic factor is the gender. Among the sample participants (142 cases), 56.8 percent are male and 43.2 percent are female. The second demographic factor is the marital status of the respondents that shows 143 cases (57.2 percent) are married and 42.8 percent are unmarried. The third demographic factor is the age of respondents that shows among the respondents to the questionnaire 40 percent are between 26 and 35 years old, 43.6 percent are between 36 to 45 years old, and 16.4 percent are between 46 to 55 years old and none of the respondents are under 25 years or over 55 years old. The forth demographic factor is the respondents' level of education that show 3.6 percent have an associate degree, $56.4 \%$ have a bachelor's degree and $40 \%$ have a Master's degree or above.

Table 1: the correlation coefficient results of the variables of the study

\begin{tabular}{|c|c|c|c|c|c|}
\hline Hypothesis & $\begin{array}{c}\text { Independent } \\
\text { variable }\end{array}$ & $\begin{array}{c}\text { Dependent } \\
\text { variable }\end{array}$ & $\begin{array}{c}\text { Significance } \\
\text { level }\end{array}$ & $\begin{array}{c}\text { Correlation } \\
\text { coefficient }\end{array}$ & $\begin{array}{c}\text { Result of } \\
\text { the test }\end{array}$ \\
\hline $\begin{array}{c}\text { The main } \\
\text { Hypothesis }\end{array}$ & $\begin{array}{c}\text { Organizational } \\
\text { culture }\end{array}$ & $\begin{array}{c}\text { Organizational } \\
\text { effectiveness }\end{array}$ & 0.000 & 0.250 & $\begin{array}{c}\mathrm{H}_{\mathrm{o}} \text { is } \\
\text { rejected }\end{array}$ \\
\hline $\begin{array}{c}\text { The first } \\
\text { hypothesis }\end{array}$ & $\begin{array}{c}\text { Adaptability } \\
\text { Culture }\end{array}$ & $\begin{array}{c}\text { Organizational } \\
\text { effectiveness }\end{array}$ & 0.766 & 0.019 & $\begin{array}{c}\mathrm{H}_{\mathrm{o}} \\
\text { confirmed }\end{array}$ \\
\hline $\begin{array}{c}\text { The second } \\
\text { hypothesis }\end{array}$ & $\begin{array}{c}\text { Involvement } \\
\text { culture }\end{array}$ & $\begin{array}{c}\text { Organizational } \\
\text { effectiveness }\end{array}$ & 0.000 & 0.602 & $\begin{array}{c}\mathrm{H}_{\mathrm{o}} \text { is } \\
\text { rejected }\end{array}$ \\
\hline $\begin{array}{c}\text { The third } \\
\text { hypothesis }\end{array}$ & Mission Culture & $\begin{array}{c}\text { Organizational } \\
\text { effectiveness }\end{array}$ & 0.000 & $0.258-$ & $\begin{array}{c}\mathrm{H}_{\mathrm{o}} \text { is } \\
\text { rejected }\end{array}$ \\
\hline $\begin{array}{c}\text { The forth } \\
\text { hypothesis }\end{array}$ & $\begin{array}{c}\text { Hierarchical } \\
\text { culture }\end{array}$ & $\begin{array}{c}\text { Organizational } \\
\text { effectiveness }\end{array}$ & 0.11 & 0.101 & $\begin{array}{c}\mathrm{H}_{\mathrm{o}} \\
\text { confirmed }\end{array}$ \\
\hline
\end{tabular}

According to the results of Table 1, at a 0.05 significant level, the hypothesis is confirmed and as a result, there is a significant relationship between the strategy of organizational culture and effectiveness. The correlation factor is direct and equal to 0.250 i.e. with an increase in the strategy of organizational culture the organizational effectiveness increases.

In order to determine that each factor of strategies of organizational culture to what extent influences the ability to predict the effectiveness of the organization, we used the stepwise regression. The results are shown in Table 2.

Table 2: the results of the model estimation to predict organizational effectiveness

Explanatory variable

Coefficient

Fixed vale

Adaptability Culture

Involvement culture

Mission Culture

Hierarchical culture

F Statistics

$$
0.724
$$

0.63

$-0.152$

$-0.081$
Dependent variable: organizational effectiveness variable

Submit Date: 01.05.2016, Acceptance Date: 20.06.2016, DOI NO: 10.7456/1060JSE/074

Copyright (C) The Turkish Online Journal of Design, Art and Communication 


\begin{tabular}{cc}
\hline P-value & $\mathbf{0 . 0 0 0}$ \\
$\mathrm{R}^{2}$ & $\mathbf{0 . 3 6 2}$ \\
Adjusted $\mathrm{R}^{2}$ & $\mathbf{0 . 3 5 9}$ \\
Durbin -Watson & $\mathbf{2 . 1 6 6}$ \\
\hline
\end{tabular}

According to Table 2, the involvement culture's factor at 95 percent level is positive and significant and as a result, they have a direct and positive correlation. The results indicate that the determined coefficient for the organizational effectiveness (i.e. dependent variable) is equal to 0.362 and this shows that $36.2 \%$ of changes in organizational effectiveness can be explained by changes in corporate culture. Considering that the Watson -Durbin statistic value is at the 1.5 to 2.5 standard distances, resulting in the independence of residuals. According to the table (4-15), the significance level calculated for these $\mathrm{F}$ statistics is 0.0000 that indicates its significance. Regression is at 95 percent level. According to the mentioned factors, the model is appropriate and the involvement culture variable can predict the organizational effectiveness.

Using the column of coefficients for organizational effectiveness the regression equation is as the following: $Y=0.724+(0.63) X 1$

\section{CONCLUSION}

Culture in an organization is similar to a man's character. Organizational culture is a phenomenon inside the organization and all parts agree that an invisible hand guides people in the direction of a typical behavior. Among the components of organizational culture, the flexibility culture and hierarchical culture do not have a significant correlation with the effectiveness and there is an inverse relationship found between mission culture and organizational effectiveness. It seems that among the components of organizational culture, corporate culture has a positive correlation with effectiveness because people are rarely separated when they work. People often work in groups and group effectiveness requires the participation of all members of the organization. Moreover, due to synergistic effects of members' participation, the organization achieves higher levels of performance, relative to their total performance that affects the organizational effectiveness.

In this study, according to the result of the first hypothesis, no relationship found between flexible culture and organizational effectiveness. To guarantee effectiveness, the existence of a support and appropriate culture is an important factor.

According to the result of the second hypothesis, since we found a significant and positive relationship between involvement culture and organizational effectiveness, officials of organizations should use the down to top decision-making approach while making some of the decisions. Successful organizations are organizations that consider human resources as the most valuable asset of the organization and their objective is to provide growth opportunities and excellence for their staff. This commitment is a fundamental value in their organizational culture and it is the success key of the organization.

According to the results of the third hypothesis, a reverse and significant relationship found between the mission culture and organizational effectiveness. This can be due to the fact that initially, strong values of a culture may increase efficiency, but if cultural control is intense and increasing, will likely cause obstacles to cultural patterns and these obstacles can reduce their effectiveness.

According to the results of the fourth hypothesis, the relationship between hierarchical culture and effectiveness, we found no significant relationship. We can assume that organizations that have a dominant hierarchy culture have a formal structure and standardized procedures that dictate the individuals' actions and the staff have the least amount of freedom and power to act. 
Overall, according to the results of the research, we suggest that managers, given its decisive role in organizational effectiveness, attempt to identify corporate culture more and this cannot be done without the participation of all the members in decisions and policies for managing the organization and more attention to individual growth. We recommend that managers consider the employee involvement at the center of their programs and thus, increase the incentive to work for employees. In this regard, they should prefer collaboration to individual participation and give priority to goal setting in the organization because setting clear goals without ambiguity and the public participation to achieve them plays a decisive role in achieving organizational effectiveness.

\section{REFERENCES}

Aarabi, S.; Moghadam,A., (2007), coordination of human resources strategies with commercial strategies and organizational culture, quarterly of management sciences, issue 8.

Abzari Mahdi, Deloi, M., (2009), achieving excellence through organizational culture, applied sociology, the twentieth year, issue (1).

Faqimahmoud, A., (2012), presentation of organizational effectiveness model of sport organization of Iraq according to competitive values approach, Master's thesis, School of physical education and sciences, university of Gilan

Ghadimi, M.; Lacani, P., (2015), a study on the the relationship between organizational culture strategies using the globe model, management development and evolution magazine, issue 22.

Gupta, b, (2010), a comparative study of organizational strategy and culture across industry, institute of management technology-bench marketing and international journal, vol 18,2011 pp 510-528.

Habibi, H.; Pardakhtchi, M.; Abolqasemi, M. Ghahremani, M., (2013), review the learning centered environment and its relation to school effectiveness research education and learning, the twentieth year, Shekareh issue 3.

Moshbeki, A., (2001), design and explain the interactive strategy model, organizational culture and environment at organizations in industrial countries, ph. D. Thesis, Tarbiat Modarres University, Tehran. Omidi; A.; Tondnevis, F.; Mozaffari, A., (2012), "communication of organizational culture with effectiveness of knowledge management and organizational effectiveness in some sport companies of Iran ", journal, management research of athletic and behavior motor, issue 4.

Rafii, M., Zahedi, S., (2012), improving the performance of an organization by coordination of strategies between human resources strategies, decision holders and organizational culture: management at organizations research, ministry of agriculture, management of organizational culture, issue 1.

Rahmanseresht, H., (2006), management strategies, cultural institute of technology and the arts, Tehran 